\title{
Pengembangan Perangkat Pembelajaran Materi SPLTV Berbasis Model Problem Based Learning Kelas X SMA/MA
}

\author{
Muhammad Rizky Pinem ${ }^{1}$, Maimunah ${ }^{2}$, Titi Solfitri ${ }^{3}$ \\ 1,2,3Program Studi Pendidikan Matematika, Fakultas Keguruan Ilmu Pendidikan, Universitas Riau \\ Jl. Bina Widya Simpang Baru, Pekanbaru \\ muhammad.rizky3840@student.unri.ac.id
}

\begin{abstract}
This research is motivated by the limited number of teacher-made mathematics learning tools that are in accordance with the 2013 Curriculum and pay attention to students' mathematical problem-solving abilities. Then the source of student learning used is only textbooks that come from the government which causes students to be less active and independent in understanding the material and solving problems. Therefore, learning tools are needed that are in accordance with the 2013 Curriculum. The purpose of this research is to produce learning device products in the form of syllabus, lesson plans, and LAS on SPLTV material based on the Problem Based Learning model that can facilitate mathematical problem-solving abilities for class $\mathrm{X}$ SMA/MA. This research is development research that refers to the 4-D model. The 4-D model was developed by Thiagarajan which includes define, design, development, and disseminate activities. Based on the data from the validation results by the validator on the syllabus, lesson plans, and LAS, the average score obtained sequentially is $3.90,3.89$, and 3.80 and is categorized as very valid. Based on the data from the student response questionnaire, the average score is 3.62 and is categorized as very practical.
\end{abstract}

Keywords: Learning Devices, Problem Based Learning, Mathematical Problem-solving Ability

\begin{abstract}
Abstrak
Penelitian ini dilatarbelakangi oleh masih terbatasnya perangkat pembelajaran matematika buatan guru yang sesuai dengan Kurikulum 2013 dan memperhatikan kemampuan pemecahan masalah matematis siswa. Kemudian sumber belajar siswa yang digunakan adalah hanya buku paket yang berasal dari pemerintah yang menyebabkan siswa menjadi kurang aktif dan mandiri dalam memahami materi dan menyelesaikan permasalahan. Oleh karena itu dibutuhkan perangkat pembelajaran yang sesuai dengan Kurikulum 2013. Tujuan penelitian ini adalah untuk menghasilkan produk perangkat pembelajaran berupa silabus, RPP, dan LAS pada materi SPLTV berbasis model Problem Based Learning dapat memfasilitasi kemampuan pemecahan masalah matematis kelas X SMA/MA. Penelitian ini merupakan penelitian pengembangan yang mengacu pada model 4D. Model 4-D dikembangkan oleh Thiagarajan yang meliputi kegiatan define (pendefinisian), design (perancangan), development (pengembangan), dan disseminate (penyebarluasan). Berdasarkan data hasil validasi oleh validator terhadap silabus, RPP, dan LAS diperoleh skor rata-rata secara berurut yaitu 3,90, 3,89, dan 3,80 dan dikategorikan sangat valid. Berdasarkan data hasil angket respon siswa diperoleh skor rata-rata yaitu 3,62 dan dikategorikan sangat praktis.
\end{abstract}

Kata Kunci: Perangkat Pembelajaran, Problem Based Learning, Kemampuan Pemecahan Masalah Matematis

Copyright (c) 2021 Muhammad Rizky Pinem, Maimunah, Titi Solfitri

$\triangle$ Corresponding author: Muhammad Rizky Pinem

Email Address: muhammad.rizky3840@student.unri.ac.id (Jl. Bina Widya Simpang Baru, Pekanbaru)

Received 15 September 2021, Accepted 07 October 2021, Published 30 December 2021

\section{PENDAHULUAN}

Kurikulum 2013 merupakan langkah lanjutan pengembangan Kurikulum Berbasis Kompetensi yang dirintis pada tahun 2004 dan KTSP 2006 yang mencakup kompetensi sikap, pengetahuan, dan keterampilan secara terpadu (Permendikbud No. 59 Tahun 2014). Dalam Permendikbud No. 59 Tahun 2014 juga dijelaskan bahwa seluruh ketentuan dalam mata pelajaran matematika yang berkaitan dengan Kurikulum 2013 sudah termuat dalam permendikbud diantaranya yaitu kompetensi inti (KI), kompetensi dasar (KD), silabus, buku teks siswa dan buku pedoman guru. Dengan kata lain bahwa 
mata pelajaran matematika memiliki kedudukan dan fungsi dalam konteks sistem pendidikan dan kurikulum.

Siswa diharapkan memperoleh manfaat melalui belajar matematika yaitu cara berpikir matematika secara sistematis, deduktif, memfasilitasi ketelitian, dan mampu memecahkan masalah dalam kehidupan nyata. Tidak jauh beda dengan manfaat matematika yang diperoleh siswa, bahwa dalam tujuan pembelajaran matematika juga dijelaskan dalam Permendikbud No. 59 Tahun 2014, yaitu 1) memahami konsep matematika; 2) menggunakan pola sebagai dugaan penyelesaian masalah dan mampu membuat generalisasi berdasarkan data; 3) menggunakan penalaran pada sifat menggunakan model matematika; 4) mengkomunikasikan gagasan; 5) memiliki sikap menghargai kegunaan dalam kehidupan; 6) memiliki sikap dan perilaku yang sesuai dengan nilai-nilai dalam matematika dan pembelajarannya; 7) melakukan kegiatan-kegiatan motorik yang menggunakan pengetahuan matematika; dan 8) menggunakan alat peraga sederhana maupun hasil teknologi untuk melakukan kegiatan-kegiatan matematik.

Menurut (Simanungkalit, 2016) bahwa berbagai upaya telah dilakukan dalam memfasilitasi pengetahuan dan pemahaman siswa tentang matematika, seperti: perubahan kurikulum matematika, penggunaan metode yang lebih konkrit dan lebih dekat dengan siswa, dan juga pengadaan dan pengembangan media ataupun perangkat pembelajaran matematika. Pernyataan tersebut juga dilanjutkan bahwa pada tahun 2013 yang lalu, sebuah terobosan kurikulum telah dirancang untuk mengembangkan pengetahuan dan pemahaman siswa tentang matematika.

Kemampuan pemecahan masalah matematis sangat penting dimiliki oleh siswa, sehinga siswa yang mampu memecahkan masalah matematika dengan baik maka akan mampu menyelesaikan masalah nyata setelah menempuh pendidikan formal (Amam, 2017). Sejalan dengan itu, Russefendi dalam (Leo Adhar, 2012) juga menyatakan bahwa kemampuan pemecahan masalah amat penting dalam matematika, tidak hanya bagi siswa yang mempelajari matematika, melainkan juga bagi siswa yang menerapkannya dalam bidang studi lain dan dalam kehidupan sehari-hari.

Dahar dalam (Ahmad \& Asmaidah, 2018) menyatakan bahwa pemecahan masalah merupakan suatu kegiatan menggabungkan konsep dan aturan yang telah diperoleh sebelumnya dan pada dasarnya merupakan tujuan utama proses pendidikan. NCTM dalam (Husna, M, Ikhsan, 2012) mengemukakan bahwa pemecahan masalah merupakan proses menerapkan pengetahuan yang diperoleh sebelumnya pada situasi baru dan berbeda.

Kemampuan pemecahan masalah matematis menurut (Simanungkalit, 2016) adalah kemampuan siswa menyelesaikan soal matematika yang tidak rutin dengan menggunakan langkah penyelesaian yang jelas dan benar. Polya dalam (Simanungkalit, 2016) juga menyatakan ada 4 indikator kemampuan pemecahan masalah matematis, yaitu: (1) Memahami masalah: mengidentifikasi unsur yang diketahui, unsur yang ditanya, memeriksa kecukupan unsur untuk penyelesaian masalah; (2) Mengaitkan unsur yang diketahui dan ditanyakan dan merumuskannya dala bentuk model matematika; (3) Memilih strategi penyelesaian, mengelaborasi dan melaksanakan 
Pengembangan Perangkat Pembelajaran Materi SPLTV Berbasis Model Problem Based Learning Kelas X SMA/MA,

perhitungan; dan (4) Menginterpretasi hasil terhadap masalah semula dan memeriksa kembali kebenaran solusi.

Data hasil Ujian Nasional di SMA/MA berdasarkan penilaian Kemendikbud bahwa nilai mata pelajaran matematika merupakan nilai terendah dari seluruh mata pelajaran yang diujikan. Hasil UN pada tahun 2019 nilai rata-ratanya sebesar 37,52. Nilai rata-rata UN pada materi aljabar sebesar 45,49. Pada tahun 2018 nilai UN mata pelajaran matematika sebesar 35,72 dan nilai rata-rata UN pada materi aljabar hanya sebesar 39,48. Pada tahun 2017 nilai rata-rata pada indikator soal siswa dapat menyelesaikan soal cerita yang berkaitan dengan SPLTV sebesar 47,33.

Berdasarkan data dari hasil Ujian Nasional matematika SMA/MA tersebut, Kemendikbud Tahun 2019 menyatakan bahwa pada pembelajaran matematika guru hendaknya memastikan siswa memahami konsep matematika dan tidak hanya menghafal prosedur menyelesaikan soal. Hal yang utama dalam pembelajaran matematika yaitu memahami konsep matematika yang kemudian dapat digunakan untuk menyelesaikan permasalahan. Jika siswa memahami konsep matematika maka akan berbanding lurus siswa mampu memecahkan masalah matematika.

Menurut (Sumartini, 2016) bahwa memfasilitasi kemampuan pemecahan masalah matematis siswa perlu didukung oleh metode pembelajaran yang tepat untuk mencapai tujuan pembelajaran. Sejalan dengan hal tersebut bahwa (Rahman, 2017) menyatakan guru harus mampu mengembangkan perangkat pembelajaran yang efektif dan menarik agar siswa mempunyai respon positif terhadap pembelajaran yang disampaikan. Perangkat pembelajaran memegang peranan penting dalam menentukan keberhasilan pelaksanaan pembelajaran (Ratumanan \& Imas Rosmiati, 2016).

Perangkat pembelajaran matematika menurut Rahmadi dalam (Astuti et al., 2019) bahwa Kurikulum 2013 menuntut guru untuk mengembangkan perangkat pembelajaran agar siswa mampu dan mempunyai modal sikap, pengetahuan dan keterampilan yang cukup yang bertujuan menyelesaikan masalah dalam kehidupan. Pedoman yang digunakan guru dalam melaksanakan pembelajaran di kelas sehingga lebih terarah menuju kompetensi yang ditetapkan adalah perangkat pembelajaran (Azka \& Santoso, 2015)

Dalam Permendikbud No. 22 Tahun 2016 bahwa silabus merupakan dasar penyusunan kerangka pembelajaran untuk setiap bahan kajian mata pelajaran. Sementara RPP merupakan rencana kegiatan pembelajaran untuk satu pertemuan atau lebih dalam upaya mencapai Kompetensi Dasar yang dikembangkan melalui silabus. Dengan demikian RPP merupakan pedoman selama pembelajaran yang lampirannya dapat berupa LAS. Dalam LAS berisi langkah-langkah yang harus dikerjakan oleh siswa untuk menemukan konsep dan dapat menyelesaiakan permasalahan kontekstual. Jadi guru berperan penting dalam merancang silabus dan RPP serta lampiran yang salah satunya adalah LAS, sehingga berkaitan dengan hal tersebut maka guru dituntut untuk profesional.

Pembelajaran Kurikulum 2013 didukung pada Permendikbud No. 103 Tahun 2014 menyatakan bahwa pembelajaran Kurikulum 2013 menggunakan pendekatan saintifik atau pendekatan berbasis proses keilmuan. Dalam Permendikbud No. 103 Tahun 2014 juga menyatakan bahwa pendekatan 
saintifik merupakan pengorganisasian pengalaman belajar melalui urutan yang logis yaitu pembelajaran mengamati, menanya, mengumpulkan informasi, menalar dan mengkomunikasikan. Melalui pendekatan saintifik, siswa akan terbiasa berpikir secara ilmiah, yaitu berpikir secara skeptik, analitis, kritis dan rasional (M. Musfiqon \& Nurdyansyah, 2015).

Permendikbud No. 103 Tahun 2014 kurikulum 2013 juga mengharapkan pembelajaran dengan menerapkan model pembelajaran salah satunya Problem Based Learning (Permendikbud No. 103 Tahun 2014). Sejalan dengan pendapat (Wardhani, 2020) bahwa konsep dan prinsip dari materi yang diajarkan akan ditemukan oleh siswa secara mandiri melaui kegiatan pembelajaran dengan menggunakan model Problem Based Learning. Menurut (Isrok'atun \& Amelia Rosmala, 2015) menyatakan bahwa Problem Based Learning adalah suatu pembelajaran yang dimulai dengan menghadapkan siswa kepada suatu permasalahan yang terdapat dalam dunia nyata dan menuntunnya untuk dapat memcahkan masalah tersebut. Model PBL menurut (Gunantara, Suarjana, 2014) bahwa pengalaman pembelajaran merupakan pusat model pembelajaran yang dapat diperoleh melalui penyelidikan dan pemecahan masalah nyata.

Berdasarkan wawancara peneliti dengan beberapa guru matematika SMA yaitu SMA Negeri 2 Siak Hulu, SMA Negeri 1 Tiga Binanga, dan SMA Negeri 15 Pekanbaru bahwa pada pembelajaran matematika guru menggunakan silabus yang diterbitkan dari Kemendikbud dan RPP yang digunakan diambil dari blog yang terdapat di media online. RPP juga belum mengacu pada suatu model pembelajaran dan belum mencantumkan materi pembelajaran yang memuat fakta, konsep, prinsip, dan prosedur sesuai dengan tuntutan Kurikulum 2013 dan yang tercantum dalam Permendikbud No. 22 Tahun 2016.

Hasil studi dokumentasi terhadap perangkat pembelajaran yang digunakan di sekolah yaitu gambaran RPP yang digunakan guru di kelas X pada salah satu sekolah. Contoh materi pembelajaran pada RPP guru disajikan pada Gambar 1.

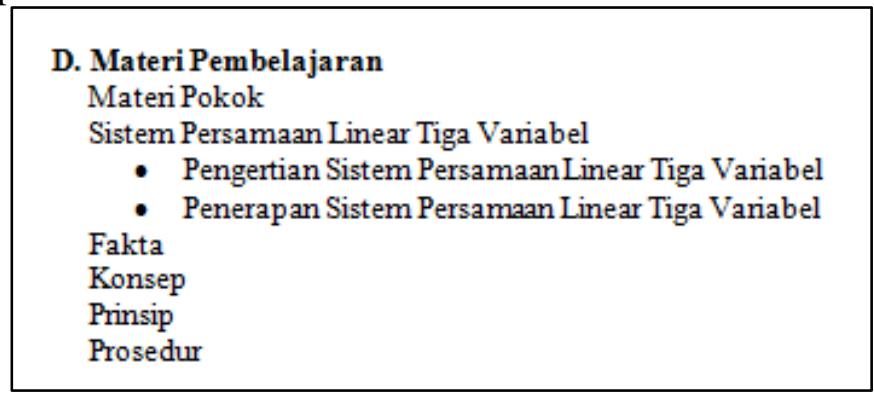

Gambar 1 Materi Pembelajaran pada RPP Guru

Sumber belajar siswa yang digunakan adalah hanya buku paket yang berasal dari pemerintah. Penggunaan buku paket tidak salah namun menyebabkan siswa menjadi kurang aktif dan mandiri dalam memahami materi dan menyelesaikan permasalahan. Hal tersebut karena guru hanya menjelaskan materi yang terdapat dalam buku paket tersebut tanpa melibatkan siswa untuk aktif yang menyebabkan siswa masih sulit untuk menyelesaikan permasalahan matematis. Pembelajaran tersebut belum sesuai dengan tuntutan Kurikulum 2013, dimana dalam kurikulum 2013 menuntut agar siswa 
Pengembangan Perangkat Pembelajaran Materi SPLTV Berbasis Model Problem Based Learning Kelas X SMA/MA,

bisa aktif atau pembelajaran tidak berpusat pada guru. Dalam pembelajaran Kurikulum 2013 siswa dituntut mampu menyelesaikan permasalahan kontekstual.

Kemudian untuk menambah data peneliti, peneliti melakukan wawancara kepada beberapa siswa SMA. Dari hasil wawancara tersebut diperoleh bahwa sebagian besar siswa mengalami kesulitan dalam memecahkan masalah matematika. Hal itu dikarenakan matematika berisi rumus dan soal cerita yang sulit dipahami. Dalam soal cerita siswa sulit untuk membuat model matematikanya sehingga sulit dalam menyelesaikan soal tersebut. Salah satu materi yang dianggap sulit dan terdapat soal yang menuntut untuk membuat model matematika yaitu materi SPLTV.

Dari beberapa penelitian sebelumnya seperti (Sari, 2020) dalam penelitiannya menemukan bahwa pembelajaran matematika yang hanya menggunakan buku yang tersedia menyebabkan ketertarikan siswa dalam belajar matematika sangat kurang. Hal itu dikarenakan materi yang disajikan dalam buku itu kurang mengaitkan masalah matematika dengan kehidupan sehari-hari siswa sehingga siswa tidak mengetahui manfaat pengetahuan yang diperolehnya dalam kehidupan sehari-hari. Kemudian penelitian yang dilakukan oleh (Heru Haerul Anwar, Anggar Titis Prayitno, 2016) dalam penelitiannya menemukan bahwa beberapa guru matematika SMA belum membuat penyajian pembelajaran yang menarik. Penyajian pembelajaran yang dimaksud adalah perangkat pembelajaran. Tidak menariknya penyajian pembelajaran menyebabkan siswa kurang aktif dalam pembelajaran dan menyebabkan hasil belajar siswa kurang memuaskan.

Pada hasil penelitian (Anggreini et al., 2019) dengan mengembangkan perangkat pembelajaran menggunakan model Problem Based Learning dapat memfasilitasi kemampuan siswa dalam menyelesaikan masalah pada materi SPLTV. Sejalan dengan hal tersebut pada hasil penelitian (Puspitasari, 2018) dengan mengembangkan perangkat pembelajaran menggunakan model Problem Based Learning dapat memfasilitasi kemampuan siswa dalam memecahkan masalah kehidupan sehari-hari. (Ramadhani, 2016) juga menunjukkan dengan menggunakan perangkat pembelajaran model PBL aktivitas siswa selama pembelajaran ada pada batasan keefektifan pembelajaran.

Berdasarkan uraian di atas peneliti terdorong mengembangkan perangkat pembelajaran matematika, yaitu silabus, RPP dan LAS yang mampu memfasilitasi kemampuan pemecahan masalah matematis kelas X SMA/MA dengan model pembelajaran Problem Based Learning (PBL). Materi SPLTV yang peneliti teliti terletak pada KD 3.3 Menyusun sistem persamaan linear tiga variabel dari masalah kontekstual 4.3 Menyelesaikan masalah kontekstual yang berkaitan dengan sistem persamaan linear tiga variabel.

\section{METODE}

Penelitian ini tergolong penelitian pengembangan yaitu suatu desain penelitian yang bertujuan untuk mengembangkan dan memvalidasi produk pendidikan (Borg dan Gall dalam (Ainin, 2013)) . Penelitian pengembangan dalam penelitian ini bertujuan untuk menghasilkan produk berupa perangkat pembelajaran yaitu silabus, RPP dan LAS menggunakan model Problem Based Learning 
(PBL) pada materi SPLTV kelas X SMA/MA dan kemudian perangkat tersebut diuji kevalidan dan kepraktisannya.

Penelitian pengembangan ini mengacu pada model 4-D. Model 4-D dikembangkan oleh Thiagarajan, Dorothy, dan Melvin (dalam (Ratumanan \& Imas Rosmiati, 2016)) yang meliputi kegiatan define (pendefinisian), design (perancangan), develop (pengembangan), dan disseminate (penyebarluasan). Model 4-D dipilih karena pada model ini terdapat analisis kebutuhan yang bertujuan untuk melihat karakteristik siswa dan dengan kondisi yang ada maka diharapkan dengan model 4-D ini dapat dikembangkan perangkat pembelajaran matematika berupa silabus, RPP, dan LAS berbasis model Problem Based Learning yang dapat digunakan sebagai referensi bagi sekolah dalam pembelajaran. Perangkat yang dikembangkan untuk materi SPLTV dapat memenuhi kriteria valid dan praktis untuk silabus, RPP, dan LAS pada jenjang SMA/MA.

\section{Analisis Data Validitas Perangkat Pembelajaran}

Analisis data hasil penilaian perangkat pembelajaran oleh validator dilakukan dengan menggunakan rumus berikut yang diadaptasi dari (Mu'tashimah et al., 2020) yaitu:

$$
\bar{M}_{v}=\frac{\sum_{i=1}^{n} \bar{V}_{i}}{n}
$$

Keterangan:

$\overline{\mathrm{M}}_{\mathrm{v}} \quad$ : rata-rata total validasi

$\overline{\mathrm{V}}_{\mathrm{i}} \quad$ : rata-rata validasi validator ke-i

n : banyaknya validator

Untuk menentukan rentang skor penilaian dilakukan dengan skor tertinggi dikurang dengan skor terendah kemudian dibagi dengan skor tertinggi, sehingga diperoleh rentang 0,75. Adapun kriteria validitas perangkat pembelajaran yang digunakan disajikan pada Tabel 1 yang diadaptasi dari (Juniantari, 2017).

Tabel 1 Kriteria Validitas Perangkat Pembelajaran

\begin{tabular}{|c|c|}
\hline Interval & Kategori \\
\hline $3,25 \leq \bar{x} \leq 4,00$ & Sangat Valid \\
\hline $2,50 \leq \bar{x}<3,25$ & Valid \\
\hline $1,75 \leq \bar{x}<2,50$ & Kurang Valid \\
\hline $1,00 \leq \bar{x}<1,75$ & Tidak Valid \\
\hline
\end{tabular}

Berdasarkan Tabel 1 bahwa perangkat pembelajaran dinyatakan valid apabila rata-rata yang diperoleh lebih dari atau sama dengan 2,50( $\bar{x} \geq 2,50)$.

\section{Analisis Data Praktikalitas Perangkat Pembelajaran}

Analisis data angket respon dilakukan dengan mengunakan rumus yang diadaptasi dari (Mu'tashimah et al., 2020):

$$
\bar{T}_{P}=\frac{\sum_{i=1}^{n} \bar{P}_{i}}{n}
$$

Keterangan: 
Pengembangan Perangkat Pembelajaran Materi SPLTV Berbasis Model Problem Based Learning Kelas X SMA/MA,

$\overline{\mathrm{M}}_{\mathrm{P}} \quad$ : rata-rata total praktikalitas

$\overline{\mathrm{P}}_{\mathrm{i}} \quad$ : rata-rata praktikalitas praktisi ke-i

n : banyaknya responden

Adapun kriteria angket respon yang digunakan disajikan pada Tabel 2 modifikasi dari (Mu'tashimah et al., 2020).

Tabel 2 Kriteria Angket Respon

\begin{tabular}{|c|c|}
\hline Interval & Kategori \\
\hline $3,25 \leq \bar{x} \leq 4,00$ & Sangat Praktis \\
\hline $2,50 \leq \bar{x}<3,25$ & Praktis \\
\hline $1,75 \leq \bar{x}<2,50$ & Kurang Praktis \\
\hline $1,00 \leq \bar{x}<1,75$ & Tidak Praktis \\
\hline
\end{tabular}

Berdasarkan Tabel 2 bahwa angket respon dinyatakan praktis apabila rata-rata yang diperoleh lebih dari atau sama dengan $2,50(\bar{x} \geq 2,50)$.

\section{HASIL DAN DISKUSI}

Penelitian ini merupakan penelitian pengembangan perangkat pembelajaran materi SPLTV berbasis model Problem Based Learning untuk memfasilitasi kemampuan pemecahan masalah matematis kelas X SMA/MA. Penelitian ini menggunakan desain 4-D (Define, Design, Development, and Disseminate).

\section{Tahap Define (Pendefenisian)}

Pada tahap define, kegiatan yang dilakukan adalah menetapkan masalah awal yang dihadapi sehingga diperlukan solusi untuk permasalahan tersebut. Pada penelitian ini masalah yang dihadapi adalah pembelajaran matematika guru menggunakan silabus yang diterbitkan dari Kemendikbud dan RPP yang digunakan diambil dari blog yang terdapat di media online. RPP juga belum mengacu pada suatu model pembelajaran dan belum mencantumkan materi pembelajaran yang memuat fakta, konsep, prinsip, dan prosedur sesuai dengan tuntutan kurikulum 2013 dan yang tercantum dalam Permendikbud No. 22 Tahun 2016. Kemudian untuk sumber belajar siswa yang digunakan adalah hanya buku paket yang berasal dari pemerintah. Penggunaan buku paket tidak salah namun menyebabkan siswa menjadi kurang aktif dan mandiri dalam memahami materi dan menyelesaikan permasalahan. Hal tersebut karena guru hanya menjelaskan materi yang terdapat dalam buku paket tersebut tanpa melibatkan siswa untuk aktif yang menyebabkan siswa masih sulit untuk menyelesaikan permasalahan matematis. Pembelajaran tersebut belum sesuai dengan tuntutan kurikulum 2013, dimana dalam kurikulum 2013 menuntut agar siswa bisa aktif atau pembelajaran tidak berpusat pada guru. Dalam pembelajaran Kurikulum 2013 siswa dituntut mampu menyelesaikan permasalahan kontekstual. Selanjutnya, peneliti menganalisis karakteristik siswa kelas X SMA/MA dengan melakukan observasi agar perangkat pembelajaran yang dikembangkan dapat digunakan oleh kemampuan siswa dengan kemampuan rendah, sedang, maupun tinggi. Setelah itu, peneliti menganalisis konsep untuk merinci dan menyusun secara sistematis konsep-konsep yang relevan yang 
dimuat pada perangkat pembelajaran pada materi sistem persamaan linear tiga variabel. Selanjutnya materi sistem persamaan linear tiga variabel dianalisis untuk menentukan tugas-tugas yang akan diberikan kepada siswa dan merumuskan tujuan pembelajaran berdasarkan IPK yang telah disusun.

\section{Tahap Design (Perancangan)}

Pada tahap design (rancangan), kegiatan yang dilakukan adalah mendesain prototype perangkat pembelajaran. Perangkat pembelajaran yang dimaksud dalam penelitian ini dibatasi pada silabus, Rencana Pelaksanaan Pembelajaran (RPP) dan Lembar Aktivitas Siswa (LAS). Perancangan silabus, RPP dan LAS disesuaikan dengan tahapan-tahapan pembelajaran Problem Based Learning dengan melibatkan KPMM siswa. Penyusunan dan sistematika silabus dan RPP yang dikembangkan berpedoman pada Permendikbud Nomor 22 tahun 2016. LAS yang dikembangkan disesuaikan dengan model Problem Based Learning dan pendekatan saintifik, serta melibatkan kemampuan pemecahan masalah matematis untuk dapat menyelesaikan masalah sistem persamaan linear tiga variabel. LAS juga memperhatikan kesesuaian syarat didaktik, syarat kontruksi, dan syarat teknis. Selain merancang perangkat pembelajaran, juga dirancang lembar validasi silabus, RPP, dan LAS, serta lembar angket respon siswa.

\section{Tahap Development (Pengembangan)}

Pada tahap development (pengembangan), dikembangkan perangkat pembelajaran yaitu silabus, RPP, dan LAS sesuai dengan rancangan awal lalu divalidasi untuk menilai tingkat kevalidan dari produk yang dikembangkan. Adapun validator yang dipilih dalam penelitian ini adalah 3 orang dosen pendidikan matematika Universitas Riau. Hasil validasi silabus disajikan pada Tabel 3, hasil validasi RPP disajikan pada Tabel 4, dan hasil validasi LAS disajikan pada Tabel 5.

Tabel 3 Data Hasil Validasi Silabus

\begin{tabular}{|l|c|c|c|c|c|}
\hline \multirow{2}{*}{ Aspek yang dinilai } & \multicolumn{3}{|c|}{$\begin{array}{c}\text { Rata-rata Penilaian } \\
\text { Validator }\end{array}$} & $\begin{array}{c}\text { Rata-rata } \\
\text { Validasi } \\
\text { Silabus }\end{array}$ & \multirow{2}{*}{ Kategori } \\
\cline { 2 - 4 } & $\mathbf{V 1}$ & $\mathbf{V 2}$ & $\mathbf{V 3}$ & \\
\hline Komponen Silabus & 4,00 & 4,00 & 4,00 & 4,00 & Sangat Valid \\
\hline Isi Silabus & 3,93 & 3,54 & 3,69 & 3,72 & Sangat Valid \\
\hline Bahasa Silabus & 4,00 & 4,00 & 4,00 & 4,00 & Sangat Valid \\
\hline $\begin{array}{c}\text { Rata-rata Validasi } \\
\text { Silabus }\end{array}$ & $\mathbf{3 , 9 7}$ & $\mathbf{3 , 8 4}$ & $\mathbf{3 , 8 9}$ & $\mathbf{3 , 9 0}$ & Sangat Valid \\
\hline
\end{tabular}

Berdasarkan Tabel 3 bahwa rata-rata skor validasi silabus dari ketiga validator untuk setiap aspek yaitu pada aspek komponen silabus skor yang diperoleh adalah 4,00 karena identitas dan komponen silabus sudah lengkap dan sesuai dengan Permendikbud No 22 Tahun 2016. Pada aspek isi silabus skor yang diperoleh adalah 3,72. Pada aspek bahasa silabus skor yang diperoleh adalah 4,00 artinya penggunaan bahasa dalam silabus jelas dan tidak memuat makna ganda. Sejalan dengan pendapat (Khuzaini, 2019) bahwa penggunaan bahasa pada silabus hendaknya tidak memuat makna ganda sehingga mudah untuk memahami bahasa tersebut. Berdasarkan hasil validasi silabus 
Pengembangan Perangkat Pembelajaran Materi SPLTV Berbasis Model Problem Based Learning Kelas X SMA/MA,

menunjukkan bahwa rata-rata skor validasi dari ketiga validator adalah 3,90 dengan kategori sangat valid.

Tabel 4 Data Hasil Validasi RPP

\begin{tabular}{|l|c|c|c|c|c|c|}
\hline \multirow{3}{*}{ Aspek yang dinilai } & \multicolumn{4}{|c|}{ Rata-rata Penilaian } & \multirow{2}{*}{$\begin{array}{c}\text { Rata-rata } \\
\text { Validator Setiap RPP }\end{array}$} & \multirow{2}{*}{\begin{tabular}{c}
\multirow{2}{*}{ Katidasi } \\
RPP
\end{tabular}} \\
\cline { 2 - 5 } & $\mathbf{1}$ & $\mathbf{2}$ & $\mathbf{3}$ & $\mathbf{4}$ & \\
\hline Komponen RPP & 4,00 & 4,00 & 4,00 & 4,00 & 4,00 & Sangat Valid \\
\hline Isi RPP & 3,57 & 3,70 & 3,70 & 3,68 & 3,66 & Sangat Valid \\
\hline Bahasa RPP & 4,00 & 4,00 & 4,00 & 4,00 & 4,00 & Sangat Valid \\
\hline Rata-rata Validasi RPP & $\mathbf{3 , 8 6}$ & $\mathbf{3 , 9 0}$ & $\mathbf{3 , 9 0}$ & $\mathbf{3 , 8 9}$ & $\mathbf{3 , 8 9}$ & Sangat Valid \\
\hline
\end{tabular}

Berdasarkan Tabel 4 bahwa rata-rata skor validasi RPP yang terdiri dari RPP-1, RPP-2, RPP-3, dan RPP-4 dari ketiga validator untuk setiap aspek yaitu pada aspek komponen RPP skor yang diperoleh adalah 4,00 karena identitas dan komponen silabus sudah lengkap dan sesuai dengan Permendikbud No 22 Tahun 2016. Pada aspek isi RPP skor yang diperoleh adalah 3,66. Sejalan dengan pendapat Agus Pahrudin (2017:76) bahwa model Problem Based Learning memiliki keterkaitan dengan pendekatan saintifik yang dapat digabungkan dalam pembelajaran. Pada aspek bahasa RPP skor yang diperoleh adalah 4,00 artinya penggunaan bahasa dalam RPP jelas dan tidak memuat makna ganda. Sejalan dengan pendapat (Khuzaini, 2019) bahwa penggunaan bahasa pada RPP hendaknya tidak memuat makna ganda sehingga mudah untuk memahami bahasa tersebut. Berdasarkan hasil validasi RPP menunjukkan bahwa rata-rata skor validasi dari ketiga validator adalah 3,89 dengan kategori sangat valid.

Tabel 5 Data Hasil Validasi LAS

\begin{tabular}{|l|c|c|c|c|c|c|}
\hline \multirow{3}{*}{ Aspek yang dinilai } & \multicolumn{4}{|c|}{ Rata-rata Penilaian } & \multirow{2}{*}{$\begin{array}{c}\text { Rata-rata } \\
\text { Validasi } \\
\text { Validator Setiap LAS }\end{array}$} & \multirow{2}{*}{ Kategori } \\
\cline { 2 - 5 } & $\mathbf{1}$ & $\mathbf{2}$ & $\mathbf{3}$ & $\mathbf{4}$ & LAS & \\
\hline Komponen LAS & 4,00 & 4,00 & 4,00 & 4,00 & 4,00 & Sangat Valid \\
\hline Isi LAS & 3,56 & 3,56 & 3,60 & 3,65 & 3,59 & Sangat Valid \\
\hline Bahasa LAS & 3,76 & 3,76 & 3,81 & 3,90 & 3,81 & Sangat Valid \\
\hline $\begin{array}{c}\text { Rata-rata Validasi } \\
\text { LAS }\end{array}$ & $\mathbf{3 , 7 7}$ & $\mathbf{3 , 7 7}$ & $\mathbf{3 , 8 0}$ & $\mathbf{3 , 8 5}$ & $\mathbf{3 , 8 0}$ & Sangat Valid \\
\hline
\end{tabular}

Berdasarkan Tabel 5 bahwa rata-rata skor validasi LAS yang terdiri dari LAS-1, LAS-2, LAS3, dan LAS-4 dari ketiga validator untuk setiap aspek yaitu pada aspek komponen LAS skor yang diperoleh adalah 4,00 artinya komponen pada LAS sudah lengkap yang memuat identitas siswa, judul materi pembelajaran, tujuan pembelajaran, dan petunjuk penggunaan LAS. Pada aspek isi LAS skor yang diperoleh adalah 3,59 artinya langkah-langkah dalam LAS sudah memuat model Problem Based Learning yang memuat KPMM. Hal ini sejalan dengan pendapat Isrok'atun dan Amelia Rosmala (2018:49) bahwa dengan kegiatan pembelajaran menggunakan model Problem Based Learning mampu melatih siswa untuk memberikan ide dalam pemecahan masalah. Pada aspek bahasa LAS skor 
yang diperoleh adalah 3,81. Berdasarkan hasil validasi LAS menunjukkan bahwa rata-rata skor validasi dari ketiga validator adalah 3,80 dengan kategori sangat valid.

Secara keseluruhan berdasarkan hasil validasi oleh validator terhadap silabus, RPP, dan LAS matematika pada materi sistem persamaan linear tiga variabel berbasis model Problem Based Learning untuk memfasilitasi kemampuan pemecahan masalah matematis siswa kelas X SMA/MA dikategorikan telah memenuhi kategori valid. Validator menyatakan silabus, RPP, dan LAS layak diujicobakan dengan revisi sesuai saran.

Setelah perangkat pembelajaran direvisi, dilakukan uji coba kelompok kecil yang terdiri dari 6 orang siswa kelas X. Uji coba dilakukan untuk melihat kepraktisan LAS yang dikembangkan dan dilakukan pada hari Selasa dan Rabu tanggal 07 dan 08 September 2021 untuk LAS-1 sampai dengan LAS-4. Uji coba untuk masing-masing LAS membutuhkan waktu 60 menit. Kepraktisan LAS dilihat berdasarkan angket respon yang diberikan kepada siswa setelah mengerjakan LAS. Adapun hasil dari angket respon siswa disajikan pada Tabel 6.

Tabel 6 Data Hasil Angket Respon Siswa Terhadap LAS

\begin{tabular}{|c|c|c|c|c|c|c|}
\hline \multirow{2}{*}{ Aspek yang dinilai } & \multicolumn{4}{|c|}{ Nilai Rata-rata Penilaian Siswa } & \multirow{2}{*}{$\begin{array}{c}\text { Rata-rata } \\
\text { Nilai } \\
\text { Angket } \\
\text { Respon }\end{array}$} & Kategori \\
\cline { 2 - 5 } & $\mathbf{1}$ & $\mathbf{2}$ & $\mathbf{3}$ & $\mathbf{4}$ & 3,74 & Sangat Praktis \\
\hline Tampilan LAS & 3,33 & 3,20 & 3,27 & 3,40 & 3,50 & Sangat Praktis \\
\hline $\begin{array}{c}\text { Isi/materi pada } \\
\text { LAS }\end{array}$ & 3,30 & 3,57 & 3,70 & 3,43 & 3,50 & Sangat Praktis \\
\hline $\begin{array}{c}\text { Kemudahan } \\
\text { pengguanaan LAS }\end{array}$ & 3,58 & 3,50 & 3,75 & 3,67 & 3,62 & $\begin{array}{c}\text { Sangat } \\
\text { Praktis }\end{array}$ \\
\hline $\begin{array}{c}\text { Rata-rata Nilai } \\
\text { Angket Respon }\end{array}$ & $\mathbf{3 , 4 1}$ & $\mathbf{3 , 4 2}$ & $\mathbf{3 , 5 7}$ & $\mathbf{3 , 5 0}$ & $\mathbf{3 , 6 2}$ & \\
\hline
\end{tabular}

Berdasarkan Tabel 6 bahwa rata-rata skor praktikalitas LAS yang terdiri dari LAS-1, LAS-2, LAS-3, dan LAS-4 dari keenam siswa yaitu pada aspek tampilan LAS skor yang diperoleh adalah 3,74 dengan kategori sangat praktis. Pada aspek isi/materi LAS skor yang diperoleh adalah 3,50 dengan kategori sangat praktis. Pada aspek kemudahan penggunaan LAS skor yang diperoleh adalah 3,62. Berdasarkan angket respon siswa, rata-rata skor yang diperoleh adalah 3,62 dengan kategori sangat praktis. Menurut responden, bahasa pada LAS yang digunakan mudah dipahami. Penyajian warna dan ilustrasi yang digunakan pada LAS menurut responden menarik. Hal ini tampak dari hasil jawaban angket respon siswa untuk aspek tampilan LAS yang memenuhi syarat didaktis.

Kegiatan yang disajikan dalam LAS menimbulkan rasa ingin tahu responden. LAS yang dikembangkan dapat memahami materi SPLTV dan dapat memfasilitasi KPMM materi SPLTV. Hal ini tampak dari hasil jawaban angket respon siswa untuk aspek isi/materi LAS yang memenuhi syarat konstrusksi. Menurut responden bahwa penyajian LAS terurut, petunjuk dalam LAS mudah dipahami, dan tulisan LAS juga mudah dibaca. Hal ini tampak dari hasil jawaban angket respon siswa untuk aspek kemudahan pengunaan LAS yang memenuhi syarat teknis. Sejalan dengan pendapat Darmojo 
Pengembangan Perangkat Pembelajaran Materi SPLTV Berbasis Model Problem Based Learning Kelas X SMA/MA, Muhammad Rizky Pinem, Maimunah, Titi Solfitri

dan Kaligis (Fitri et al., 2017) bahwa LAS dapat memudahkan pengajaran jika dalam pengembangannya memenuhi syarat didaktik, syarat konstruksi, dan syarat teknis.

Berdasarkan uraian hasil validasi terhadap silabus, RPP, dan LAS, kemudian hasil angket respon siswa terhadap keterlaksanaan LAS matematika pada materi sistem persamaan linear tiga variabel dapat disimpulkan bahwa silabus, RPP, dan LAS yang dikembangkan memenuhi kriteria sangat valid dan sangat praktis untuk digunakan dalam pembelajaran. Sebagaimana pendapat (Kawiyah, 2015) bahwa perangkat pembelajaran yang telah memenuhi kriteria valid dan praktis serta dapat digunakan dalam pembelajaran. Selanjutnya pada tahap penyebarluasan yaitu penggunaan perangkat pembelajaran yang telah dikemas dan dikembangkan pada skala yang lebih luas yaitu kelas dan sekolah lain.

Produk berdasarkan hasil validasi dan uji coba kelompok kecil terdapat kelebihan dan kelemahan. Kelebihan produk ini yaitu dapat dijadikan sebagai salah satu alternatif perangkat pembelajaran yang dapat digunakan guru dalam pembelajaran karena telah memenuhi kriteria valid dan praktis. Sedangkan kelemahannya yaitu produk yang dikembangkan peneliti hanya pada uji coba kelompok kecil yang dilakukan pada 6 orang siswa dikarenakan adanya pembelajaran tatap muka terbatas yang diberlakukan oleh pemerintah. Selain itu, pada penelitian pengembangan ini peneliti hanya mengukur aspek kevalidan dan kepraktisan produk. Peneliti menyarankan agar dapat dilakukan penelitian yang dapat mengukur keefektivitasan produk.

\section{Tahap Disseminate (Penyebarluasan)}

Pada tahap penyebarluasan adalah penggunaan perangkat pembelajaran yang telah dikemas dan dikembangkan pada sekolah lain. Pengemasan produk disajikan pada Gambar 2.

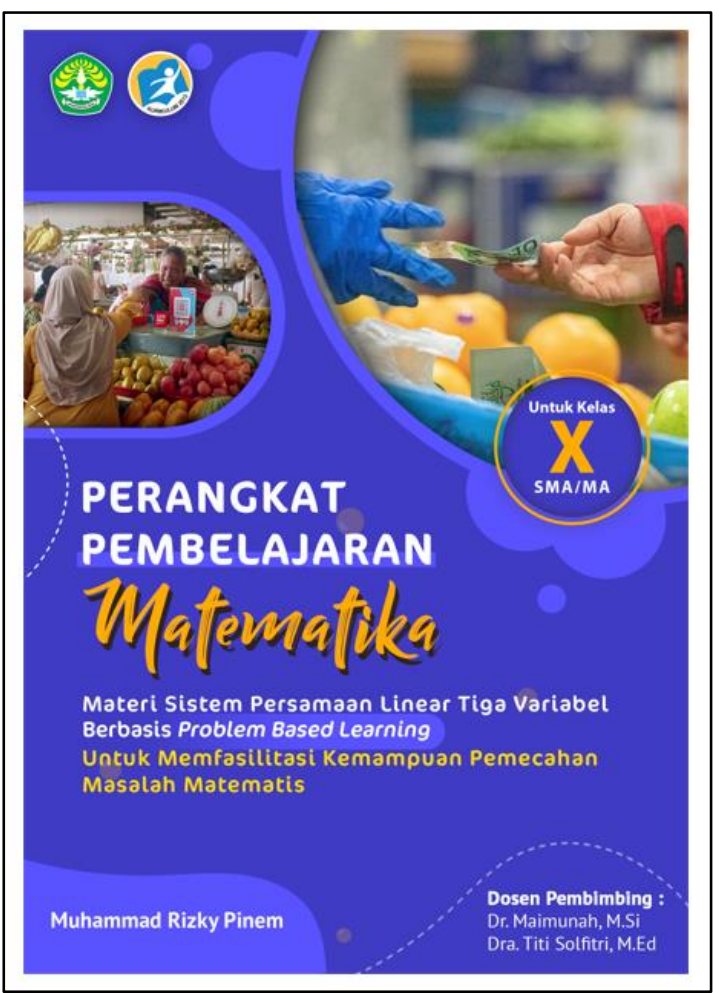

Gambar 2. Pengemasan Produk 


\section{KESIMPULAN}

Penelitian pengembangan ini menghasilkan suatu produk berupa perangkat pembelajaran matematika berupa silabus, RPP, dan LAS materi sistem persamaan linear tiga variabel berbasis model Problem Based Learning untuk meningkatkan kemampuan pemecahan masalah matematis siswa kelas X SMA/MA. Peneliti mengembangkan perangkat pembelajaran matematika dengan menggunakan model pengembangan 4-D yang terdiri dari 4 tahap pengembangan yaitu pendefenisian (define), perancangan (design), pengembangan (develop), dan penyebaran (disseminate). Perangkat pembelajaran yang dikembangkan, kemudian divalidasi. Setelah memenuhi kriteria valid dan direvisi sesuai saran, produk diujicobakan dengan uji coba kelompok kecil pada siswa SMA Nurul Falah Pekanbaru untuk melihat kepraktisan LAS. Berdasarkan hasil validasi dan uji coba yang dilakukan, diperoleh bahwa perangkat pembelajaran materi sistem persamaan linear tiga variabel berbasis model Problem Based Learning untuk memfasilitasi kemampuan pemecahan masalah matematis kelas $\mathrm{X}$ SMA/MA telah dinilai memenuhi kriteria valid dan praktis untuk digunakan dalam pembelajaran.

\section{UCAPAN TERIMA KASIH}

Ucapan terimakasih ditujukan kepada guru matematika dan siswa di sekolah SMA Nurul Falah Pekanbaru yang telah mengizinkan peneliti untuk melakukan penelitian ini.

\section{REFERENSI}

Ahmad, M., \& Asmaidah, S. (2018). Pengembangan Perangkat Pembelajaran Matematika Realistik Untuk Membelajarkan Kemampuan Pemecahan Masalah Matematika Siswa Smp. Mosharafa: Jurnal Pendidikan Matematika, 6(3), 373-384.

Ainin, M. (2013). Penelitian Pengembangan Dalam Pembelajaran Bahasa Arab. OKARA: Jurnal Bahasa Dan Sastra, 7(2), 96-110.

Amam, A. (2017). Penilaian Kemampuan Pemecahan Masalah Matematis Siswa Smp. Teorema, 2(1), 39. Anggreini, E., Zulkarnain, \& Ariawan, R. (2019). Pengembangan Perangkat Pembelajaran Matematika dengan Problem Based Learning (PBL) pada Materi Sistem Persamaan Linear Tiga Variabel di Kelas X SMK Yabri Terpadu Pekanbaru Erna Anggreini. Aksiomatik, 7(1), 34-40.

Astuti, P. H. M., Margunayasa, I. G., \& Suarjana, I. M. (2019). Pengembangan Perangkat Pembelajaran Kolaboratif pada Mata Pelajaran Matematika Topik Kubus dan Balok. Jurnal Ilmiah Sekolah Dasar, 3(3), 271.

Azka, R., \& Santoso, R. H. (2015). Pengembangan Perangkat Pembelajaran Kalkulus Untuk Mencapai Ketuntasan Dan Kemandirian Belajar Siswa. Jurnal Riset Pendidikan Matematika, 2(1), 78 .

Fitri, R. A., Noviana, E., \& Fendrik, M. (2017). Pengembangan Lembar Kerja Siswa (LKS) pada Mata Pelajaran Matematika Kelas 5 Sekolah Dasar (Penelitian Pengembangan dengan Materi Volume Kubus dan Balok di SD IT Al-Fityah). Jurnal Online Mahasiswa Fakultas Keguruan 
Pengembangan Perangkat Pembelajaran Materi SPLTV Berbasis Model Problem Based Learning Kelas X SMA/MA,

Dan Ilmu Pendidikan Universitas Riau, 4(1), 1-12.

Gunantara, Suarjana, N. R. (2014). Penerapan Strategi Pembelajaran Problem Based Learning Untuk Meningkatkan Kemampuan Pemecahahan Masalah Matematis Siswa Kelas IV. Kreano, Jurnal Matematika Kreatif-Inovatif, 10(2), 146-152.

Heru Haerul Anwar, Anggar Titis Prayitno, M. R. (2016). Pengembangan Perangkat Pembelajaran Matematika yang Berorientasi pada Model Problem Based Learning. Kreano, Jurnal Matematika Kreatif-Inovatif, 7(2), 116-122.

Husna, M, Ikhsan, S. F. (2012). Peningkatan Kemampuan Pemecahan Masalah Dan Komunikasi Matematis Siswa Sekolah Menengah Pertama Melalui Model Pembelajaran Kooperatif Tipe Think-Pair-Share (Tps). Jurnal Peluang, 1(2), 81-92.

Juniantari, M. (2017). Pengembangan Perangkat Pembelajaran Matematika Berorientasi Pendidikan Karakter Dengan Model Treffinger Bagi Siswa Sma. Journal of Education Technology, 1(2), 71. Kawiyah, S. (2015). Pengembangan Perangkat Pembelajaran Matematika Berbasis Saintifik untuk Meningkatkan Kemampuan Pemecahan Masalah dan Prestasi Belajar Siswa. PYTHAGORAS: Jurnal Pendidikan Matematika, 10(2), 201.

Khuzaini, N. (2019). Pengembangan Media Pembelajaran Berbasis Multimedia Interaktif Menggunakan Adobe Flash CS3 Dengan Pendekatan Matematika Realistik Untuk Meningkatkan Komunikasi Matematis Siswa Pada Pokok Bahasan Lingkaran. Prosiding Sendika, 5(1), 569575.

Leo Adhar, E. (2012). Pembelajaran Matematika dengan Metode Penemuan Terbimbing Untuk Meningkatkan Kemampuan Representasi dan Pemecahan Masalah Matematis Siswa SMP. Jurnal Penelitian Pendidikan, 13(2), 1-10.

Mu'tashimah, A., Putri, A. D., \& Ramury, F. (2020). Lilin sebagai Konteks Materi Tabung pada LKPD Berbasis PMRI. JKPM (Jurnal Kajian Pendidikan Matematika), 6(1), 83.

Puspitasari, F. D. (2018). Pengembangan Perangkat Pembelajaran Problem Based Learning (PBL) Menggunakan Pop Up Book Pada Materi Trigonometri. In Gastrointestinal Endoscopy (Vol. 10, Issue 1).

Rahman, A. A. (2017). Pengembangan Perangkat Pembelajaran Berbasis Pendekatan Realistik Untuk Meningkatkan Kemampuan Pemecahan Masalah Matematis Siswa SMP N 3 Langsa. Jurnal MAJU, 4(1), 26-37.

Ramadhani, R. (2016). Pengembangan Perangkat Pembelajaran Matematika yang Berorientasi pada Model Problem Based Learning. Kreano, Jurnal Matematika Kreatif-Inovatif, 7(2), 116-122.

Sari, S. M. (2020). Pengembangan Perangkat Pembelajaran Problem Based Learning (PBL) dalam Pembelajaran Matematika di SMA. Jurnal Serambi Ilmu, 21(2), 211-228.

Simanungkalit, R. H. (2016). Pengembangan Perangkat Pembelajaran untuk Meningkatkan Kemampuan Pemecahan Masalah Matematis Siswa SMP Negeri 12 Pematangsiantar. MUST: Journal of Mathematics Education, Science and Technology, 1(1), 39. 
Sumartini, T. S. (2016). Analisis Peningkatan Kemampuan Koneksi Matematis Mahasiswa Ptik Melalui Pembelajaran Berbasis Masalah. 5.

Wardhani, R. S. (2020). Pengembangan Perangkat Pembelajaran Matematika Menggunakan Model Problem Based Learning Pada Materi Sistem Persamaan Linier Tiga Variabel Untuk Peserta Didik Kelas X SMA / MA. 3(2), 42-55. 